\title{
Antiproliferation of human prostate cancer cells by ethanolic extracts of Brazilian propolis and its botanical origin
}

\author{
HONGZHEN LI ${ }^{1}$, ANEESH KAPUR ${ }^{1}$, JESSE X. YANG ${ }^{1}$, SHIV SRIVASTAVA ${ }^{1}$, DAVID G. McLEOD ${ }^{1}$, \\ JULIO F. PAREDES-GUZMAN ${ }^{2}$, ANDREAS DAUGSCH ${ }^{2}$, YONG K. PARK ${ }^{2}$ and JOHNG S. RHIM ${ }^{1}$ \\ ${ }^{1}$ Center for Prostate Disease Research, Uniformed Services University of the Health Sciences, Bethesda, MD, USA; \\ ${ }^{2}$ State University of Campinas (UNICAMP), College of Food Engineering Caixa Postal, Rua Monteiro Lobato, Brazil
}

Received November 2, 2006; Accepted January 2, 2007

\begin{abstract}
Propolis is a resinous substance collected by bees (Apis mellifera) from various tree buds which they then use to coat hive parts and to seal cracks and crevices in the hive. Propolis, a known ancient folk medicine, has been extensively used in diet to improve health and to prevent disease. In the present study, we have evaluated the effects of ethanolic extracts of Brazilian propolis group 12 and bud resins of botanical origin (B. dracunculifolia), and propolis group 3 on proliferation of metastasis (DU145 and PC-3) and primary malignant tumor (RC58T/h/SA\#4)-derived human prostate cancer cells. The strongest inhibition was observed in propolis group 3 (sample \#3) extracts whereas moderate growth inhibition was observed in human prostate epithelial cells. In the $\mathrm{RC} 58 \mathrm{~T} / \mathrm{h} / \mathrm{SA \# 4}$ cells, resins of botanical origin of propolis group 12 (sample \#1) and propolis group 12 (sample \#2) induced growth inhibition that was associated with $\mathrm{S}$ phase arrest whereas propolis group 3 (sample \#3) induced growth inhibition that was associated with G2 arrest. The mechanisms of cell cycle effects of propolis were investigated. The resins of botanical origin of propolis group 12 and propolis group 12 showed similar inhibition of cyclin D1, CDK4 and cyclin B1 expression. Propolis group 3 showed higher induction of p21 expression but no inhibition of cyclin D1, CDK4 and cyclin B1 expression. The results obtained here demonstrate that the Brazilian propolis extracts have significant inhibitory effect on proliferation of human prostate cancer cells. Inhibition was achieved through regulation of protein expression of cyclin D1, B1 and cyclin dependent kinase (CDK) as well as
\end{abstract}

Correspondence to: Dr Johng S. Rhim, Center for Prostate Disease Research, Department of Surgery, Uniformed Services University of the Health Sciences, 4301 Jones Bridge Road, Bethesda, MD 20814, USA

E-mail: jrhim@cpdr.org

Abbreviations: hTERT, human telomerase reverse transcriptase; K-SFM, keratinocyte-serum-free medium; GI50, growth inhibition of $50 \%$

Key words: malignant human prostate cancer cells, antiproliferation, Brazilian propolis, cell cycle p21. Our results indicate that the Brazilian propolis extracts show promise as chemotherapeutic agents as well as preventive agents against prostate cancer.

\section{Introduction}

Prostate cancer is the most common male cancer in USA and other Western countries, and the second leading cause of male cancer death in USA (1). Despite its pervasive impact, the etiology of prostate cancer and the factors that promote its progression are not well understood. To date, there is no secure way to tell whether prostate cancer, once found, should receive treatment. Although prostatectomy, radiation therapy and hormone therapy have been used for curing prostate cancer patients, recurrence and metastasis of prostate cancer are major problems in prostate cancer therapy. Current available treatment often has troubling side-effects such as urinary incontinence and erectile dysfunction. There is no effective treatment modality once the cancer has evolved into the hormone refractory stage. Preventive strategies are currently emerging. These is an increase in the usage of nutritional supplements such as soybeans, garlic, green tea and Vitamin D3 etc., to augment the prescribed anticancer therapies.

Propolis is a resinous substance collected by Apis mellifera from various tree buds which they then use to coat hive parts and to seal cracks and crevices in the hive (2). Propolis has been used as a folk medicine since ca. 300 BC (3). Recently, numerous biological properties of propolis have been reported including cytotoxic, antiherpes, antitumor, free radical scavenging, antimicrobial, and anti-HIV activities (4-10). Because of the wide range of biological activities, recently propolis has been extensively used in food and beverages to improve health and prevent diseases (11-13).

The medical application of propolis preparation has led to increased interest in its chemical compositions and its botanical origins, because so far mainly polyphenol compounds have been identified in propolis collected by Apis mellifera, the main polyphenols being flavonoid aglycones, and its derivatives (14). The chemical composition of the main flavonoids in propolis has been found to be quantitatively or qualitatively variable, depending on the environmental plant ecology (15-17).

Previously, we have collected 500 samples of propolis obtained by Africanized Apis mellifera in Brazil. We found that Brazilian propolis contained 12 groups based on physico- 
chemical characteristics, and some of the ethanolic extracts of propolis inhibited the growth of rapidly growing solid tumor cell lines. Thus, groups 1,2, 6, and 7 are highly antagonistic to the growth of nasopharyngel carcinoma (KB), and groups 6 and 7 are also highly inhibitive against the growth of ileocecal adenocarcinoma (HCT-8), renal carcinoma CAKE-1, and breast carcinoma (MCT-7) tumor cell lines $(17,18)$. The propolis group 12, which is known as green propolis, is widely used mainly for ingredients of functional foods and pharmaceutical purposes $(15,16)$. The botanical origin of propolis group 12 was the resin of the leaf bud of Baccharis dracunculifolia in southeastern Brazil. Propolis group 3 was collected in southern Brazil. In the present study we have evaluated the effects of ethanolic extracts of the propolis groups 3 and 12, and bud resins of botanical origin of propolis group 12 on proliferation of metastasis and primary tumorderived human prostate cancer cells.

\section{Materials and methods}

Preparation of experimental samples. Two ethanolic extracts of propolis groups 3 (sample \#3) and 12 (sample \#2) were prepared as follows. Each group of propolis sample $(50 \mathrm{~g})$ was extracted with $600 \mathrm{ml}$ of $80 \%(\mathrm{v} / \mathrm{v})$ ethanol at $60^{\circ} \mathrm{C}$ for $30 \mathrm{~min}$. After extraction, the mixture was centrifuged and the supernatant were individually evaporated to complete dryness at $40^{\circ} \mathrm{C}$ and the resulting powder was designated as ethanolic extracts of propolis. In the case of ethanolic extracts of botanical origin of propolis group 12, the leaf buds of $B$. dracunculifolia were removed with a knife without breaking them into pieces, and immeditely $20 \mathrm{~g}$ of buds were rinsed with $200 \mathrm{ml}$ of $80 \%$ ethanol at $70^{\circ} \mathrm{C}$ for $1 \mathrm{~h}$ to remove superficial resins, centrifuged to separate the supernatant and then evaporated as mentioned above. The three samples were classified as follows: sample \#1 is botanical origin of propolis group 12, sample \#2 is propolis group 12, and sample \#3 is propolis group 3. The three samples were analyzed by Reversed-Phase High-Performance Liquid Chromatography (RPHPLC) and the results are described in Table I. Genistein was used as positive control and it was purchased from Sigma (St. Louis, MO).

Cell culture. Metastasis-derived human prostate cancer cell lines (DU145 and PC-3) were obtained from American Type Culture Collection (ATCC, Manassas, VA) and maintained in RPMI-1640 medium supplemented with 10\% fetal bovine serum (Invitrogen, Carlsbad, CA). Telomerase-immortalized primary human prostate cancer-derived cell line (RC-58T/h/ SA\#4) (19) and primary human prostate epithelial cells (PrEC) (Cambrex Bioproducts, Walkersville, MD) were grown and maintained in the keratinocyte serum-free medium (K-SFM) supplemented with bovine pituitary extract and recombinant epidermal growth factor (KGM) (Life Technologies, Inc. Gaithersburg, MD).

Cell proliferation assays. The cell growth assays were carried out by using CellTiter 96 Aqueous One solution cell proliferation assay kit (Promega, Madison, WI). Briefly, 5000 cells/well were plated in 96-well plates, and desired concentrations of propolis were added on the following day.
Table I. Flavonoids and other constituents of propolis groups 3, 12 , and botanical origin of propolis group 12 .

\begin{tabular}{|c|c|c|c|}
\hline Compounds & $\begin{array}{c}\text { Propolis } \\
\text { group } 3 \\
\text { (sample \#3) } \\
\mathrm{Mg} / \mathrm{g}\end{array}$ & $\begin{array}{c}\text { Propolis } \\
\text { group } 12 \\
\text { (sample \#2) } \\
\text { Mg/g }\end{array}$ & $\begin{array}{c}\text { Origin } \\
\text { botanic } \\
\text { (sample \#1) } \\
\mathrm{Mg} / \mathrm{g}\end{array}$ \\
\hline Coumaric acid & 4.8 & 8.5 & 4.3 \\
\hline Ferulic acid & 1.3 & 2.4 & 4.8 \\
\hline Cinnamic acid & - & - & 0.68 \\
\hline Pinobanksin & 54.9 & 8.7 & 7.2 \\
\hline Kaempferol & 3.4 & 0.4 & 1.10 \\
\hline Apigenin & 4.8 & - & - \\
\hline Isosakuranetin & - & 7.3 & 1.22 \\
\hline Pinocembrin & 54 & - & - \\
\hline $\begin{array}{l}\text { Dimethylallyl } \\
\text { caffeic acid }\end{array}$ & 2.2 & - & - \\
\hline $\begin{array}{l}\text { Pinobanksin-3- } \\
\text { acetate }\end{array}$ & 64.9 & - & - \\
\hline Chrysin & 54 & 1.86 & 1.05 \\
\hline Galangin & 35.7 & - & - \\
\hline Kaempferide & - & 12.5 & 8.15 \\
\hline Tectochrysin & 11.3 & - & - \\
\hline Artepillin C & - & 38.58 & 40.54 \\
\hline
\end{tabular}

After treatment for $48 \mathrm{~h}$, detection reagents (MTS) were added, and cells were incubated for $1 \mathrm{~h}$. Absorbance was measured at $492 \mathrm{~nm}$ in a 96-well plate reader.

Cell cycle analysis. The one day-old cultures $\left(2 \times 10^{6}\right.$ cells $)$ were exposed to various doses of propolis. After 48-h treatment, cells were harvested with PBS-EDTA buffer, and were fixed (1 volume of cold PBS, 3 volumes of cold 200 proof ethanol) while vortexing. The single cell suspension was treated with RNAse and propidium iodide was added. The samples were filtered and run on a cytometer. The results were analysed by using Modfit LT software package (Verity Software house, Inc. Topsham Maine).

Western blot analysis. The cells were harvested from T25 flasks after 48-h treatment with propolis, washed once with PBS and cell pellets were stored at $-70^{\circ} \mathrm{C}$. Cell protein was extracted with T-PER tissue protein extraction reagent (Pierce, Rockford, IL). The protein concentration was determined with BCA protein assay kit (Pierce). Twenty $\mu \mathrm{g}$ of protein from each lysate was subjected to $4-12 \%$ SDS-PAGE under reducing conditions. The primary antibodies, cyclin B1 (V152) mouse monoclonal antibody, cyclin D1 polyclonal antibody, CDK4 (DCS156) mouse monoclonal antibody and p21 (DCS60 \#2946) antibody (Cell Signaling, Bevely, MA), were used at a 1:2000 dilution. Antigen-antibody complexes were detected by horseradish peroxidase-conjugated secondary antibodies in conjunction with enhanced chemiluminesence substrate mixture (Pierce) and exposed to film. 
A
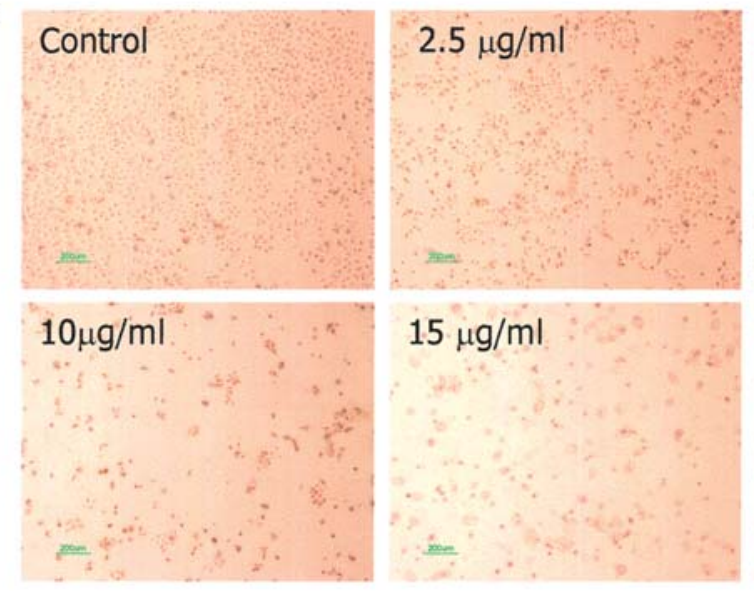

$\mathrm{B}$

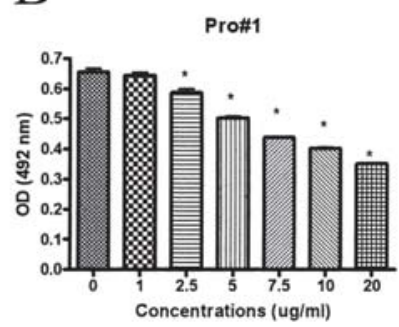

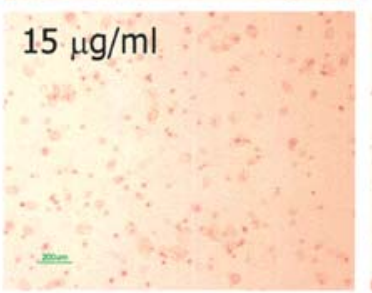

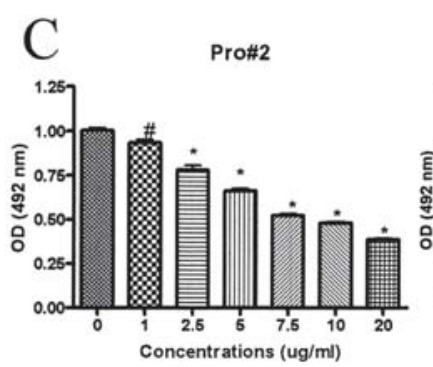

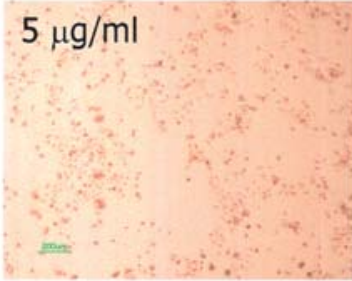

$20 \mu \mathrm{g} / \mathrm{ml}$
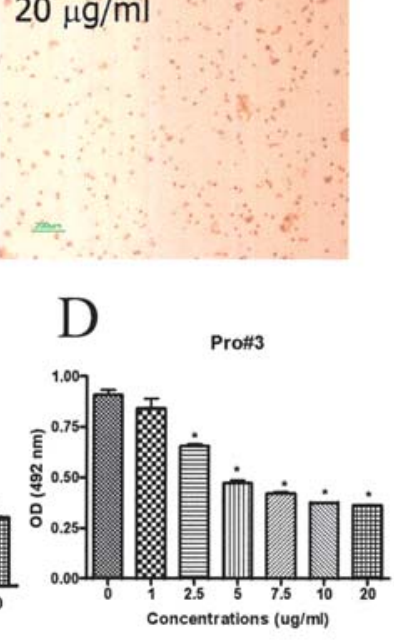

Figure 1. Propolis inhibited cell proliferation in primary malignant tumor-derived human prostate cancer cell line (RC-58T/h/SA\#4). A, growth and morphology of RC58T/h/SA\#4 cells exposed to various doses of propolis \#1. The cell growth was inhibited at $2.5 \mu \mathrm{g} / \mathrm{ml}$ and completely inhibited at $20 \mu \mathrm{g} / \mathrm{ml}$. A change in the cell morphology from late and round into thin and spines was observed with 10 and $15 \mu \mathrm{g} / \mathrm{ml}$ of propolis \#1. B, the cells were cultured in the KGM. The RC58T/h/SA\#4 cells, 5000/well were plated in 96-well plates and on the following day, they were treated with either EtOH vehicle control or various doses of propolis. After 48-h treatment, the cells were washed with KGM medium and viable cells were counted using a CellTiter 96 Aqueous One solution cell proliferation assay kit (Cat\#3581 Promega). Each sample was counted in 6 wells and repeated three times. The data was statistically analyzed by one-way ANOVA analysis. ${ }^{*} \mathrm{P}<0.01$. A, propolis \#1; C, propolis \#2; and D, propolis \#3.

\section{Results}

Three propolis samples inhibited cell growth of primary human prostate cancer cell line. The RC58T/h/SA\#4 cell line was derived from a soft agar clone of the RC-58T/h cell line, a telomerase-immortalized primary malignant tumor-derived human prostate epithelial cell line (19) grown in KGM. To find the optimal dose for various propolis inhibition on prostate cancer cells, the cell growth was determined in the presence of various doses of propolis (Fig. 1). The samples showed significant inhibition of cell growth (Fig. 1A and B) and induced also morphological alterations such as polygonal to spindle cells (Fig. 1A, 10 and $15 \mu \mathrm{g} / \mathrm{ml}$ ). The cells died at $20 \mu \mathrm{g} / \mathrm{ml}$ treated cells. To determine the dose-dependent growth inhibitory efficiency, we have tested the cell viability of RC-58T/h/SA\#4 and PrEC cells with propolis samples \#1, $\# 2$ and \#3 (Fig. 1B-D) on RC-58T/h/SA\#4 cells. The $50 \%$ growth inhibition (GI50) of propolis was $5.5 \mu \mathrm{g} / \mathrm{ml}$ for sample \#1 (botanical origin of propolis group 12); $5 \mu \mathrm{g} / \mathrm{ml}$ for sample \#2 (propolis group 12), and $3 \mu \mathrm{g} / \mathrm{ml}$ for sample \#3 (propolis group 3). All the samples had higher inhibitory efficiency in primary prostate cancer cells compared to normal human prostate epithelial cells (Table II).

Three propolis samples inhibited cell growth of metastasisderived human prostate cancer cell lines. To further examine the inhibition of cell growth by the samples, we also tested
Table II. The 50\% growth inhibition of normal human prostate epithelial (PrEC) and primary tumor-derived human prostate cancer (RC-58T/h/SA\#4) cells and by propolis \#1, \#2 and \#3.

\begin{tabular}{llc}
\hline & PrEC & RC58T/h/SA\#4 \\
\hline Propolis \#1 & 7.5 & 5.5 \\
Propolis \#2 & 8.75 & 5 \\
Propolis \#3 & 5.5 & 3 \\
\hline
\end{tabular}

PrEC, primary human prostate epithelial cells.

the metastasis-derived human prostate cancer cell lines (DU145 and PC-3) and RC-58T/h/SA\#4 cells grown in RPMI-1640 with $10 \%$ fetal bovine serum. DU145 cells were derived from brain metastasis of a prostate cancer patient and PC-3 cells were derived from bone metastasis of a prostate cancer patient. Samples \#1, \#2, \#3 and genistein showed similar inhibitory efficiency in RC58T/h/SA\#4 cells (Fig. 2A). However stronger inhibition of cell growth was observed in DU145 (Fig. 2B) and PC3 (Fig. 2C). The optimal dose of cell growth inhibition efficiency was $40 \mu \mathrm{g} / \mathrm{ml}$ in DU145 and PC-3 cells and $80 \mu \mathrm{g} / \mathrm{ml}$ in $\mathrm{RC}-58 \mathrm{~T} / \mathrm{h} / \mathrm{SA \# 4}$ cells, respectively. The results indicated that the cell growth inhibition efficiency of propolis samples 


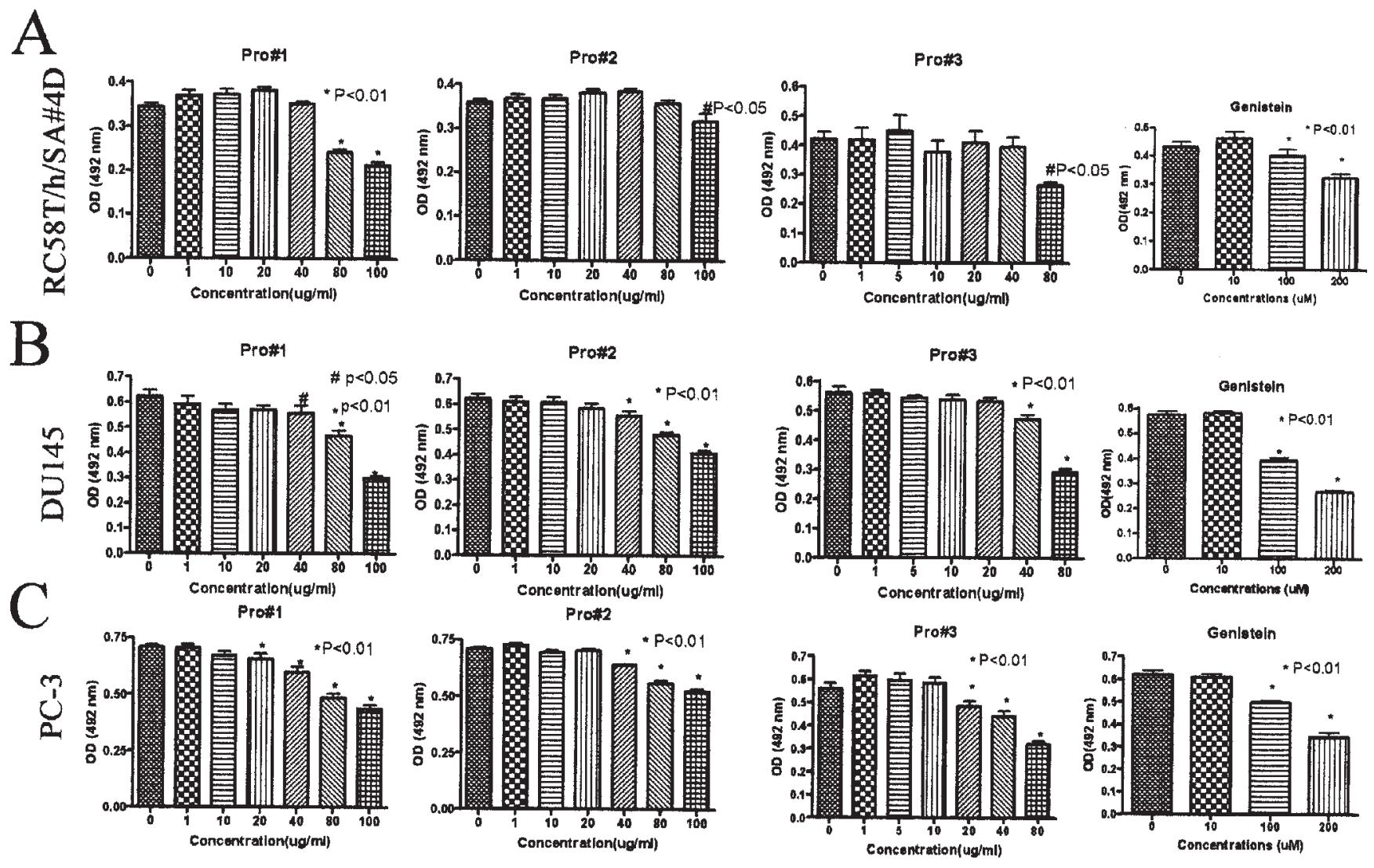

Figure 2. Propolis inhibited cell proliferation of metastasis and primary tumor-derived human prostate cancer cell lines (RC-58T/h/SA\#4, DU145 and PC-3 cells). The cells were cultured in RPMI with 10\% fetal bovine serum. The prostate cancer cells, 5000/well were plated in 96-well plates and on the following day, they were treated with either EtOH vehicle control or various concentrations of propolis in the same medium. After 48-h treatment, the cells were washed with PBS and viable cells were detected using a CellTiter 96 Aqueous One solution cell proliferation assay kit (Cat\#3581 Promega). Each sample was counted in 6 wells. The data was statistically analyzed by one-way ANOVA analysis. ${ }^{*} \mathrm{P}<0.05$; ${ }^{*} \mathrm{P}<0.01$. A, RC58T/h/SA\#4 (DMEM); B, DU145; C, PC-3.

Table III. Inhibition of metastasis-derived (DU145 and PC-3) and primary tumor-derived (RC-58T/h/SA\#4) human prostate cancer cell lines by propolis \#1-3.

\begin{tabular}{|c|c|c|c|c|c|c|}
\hline \multirow[t]{2}{*}{ Cells } & \multicolumn{2}{|c|}{ Propolis \#1 } & \multicolumn{2}{|c|}{ Propolis \#2 } & \multicolumn{2}{|c|}{ Propolis \#3 } \\
\hline & $80 \mu \mathrm{g} / \mathrm{ml}$ & $100 \mu \mathrm{g} / \mathrm{ml}$ & $80 \mu \mathrm{g} / \mathrm{ml}$ & $100 \mu \mathrm{g} / \mathrm{ml}$ & $40 \mu \mathrm{g} / \mathrm{ml}$ & $80 \mu \mathrm{g} / \mathrm{ml}$ \\
\hline \multicolumn{7}{|l|}{ DU145 } \\
\hline $2 \%$ serum & 80.2 & 93.0 & 76.9 & 79.9 & 65.1 & 88.29 \\
\hline $10 \%$ serum & 31.0 & 64.4 & 28.3 & 43.1 & 20.8 & 63.9 \\
\hline \multicolumn{7}{|l|}{ PC3 } \\
\hline $2 \%$ serum & 93.6 & 98.6 & 92.2 & 95.5 & 62.1 & 92.1 \\
\hline $10 \%$ serum & 39.0 & 48.0 & 26.6 & 32.8 & 24.5 & 57.2 \\
\hline \multicolumn{7}{|c|}{ RC58T/h/SA\#4 } \\
\hline $2 \%$ serum & 88.2 & 95.3 & 83.0 & 90.8 & 42.0 & 84.7 \\
\hline $10 \%$ serum & 51.4 & 65.8 & 0.02 & 19.18 & 9.6 & 56.2 \\
\hline
\end{tabular}

was higher in metastatic human prostate cancer cell lines than in the primary human prostate cancer cell line.

Effect of serum on the cell growth inhibition by propolis samples. To test whether the serum concentration in the culture condition interferes with the inhibition of cell growth by the samples, we examined the cells in the presence of various serum concentrations. The results showed that the cell growth inhibition of propolis samples was attenuated and reversed by the serum (Table III). 


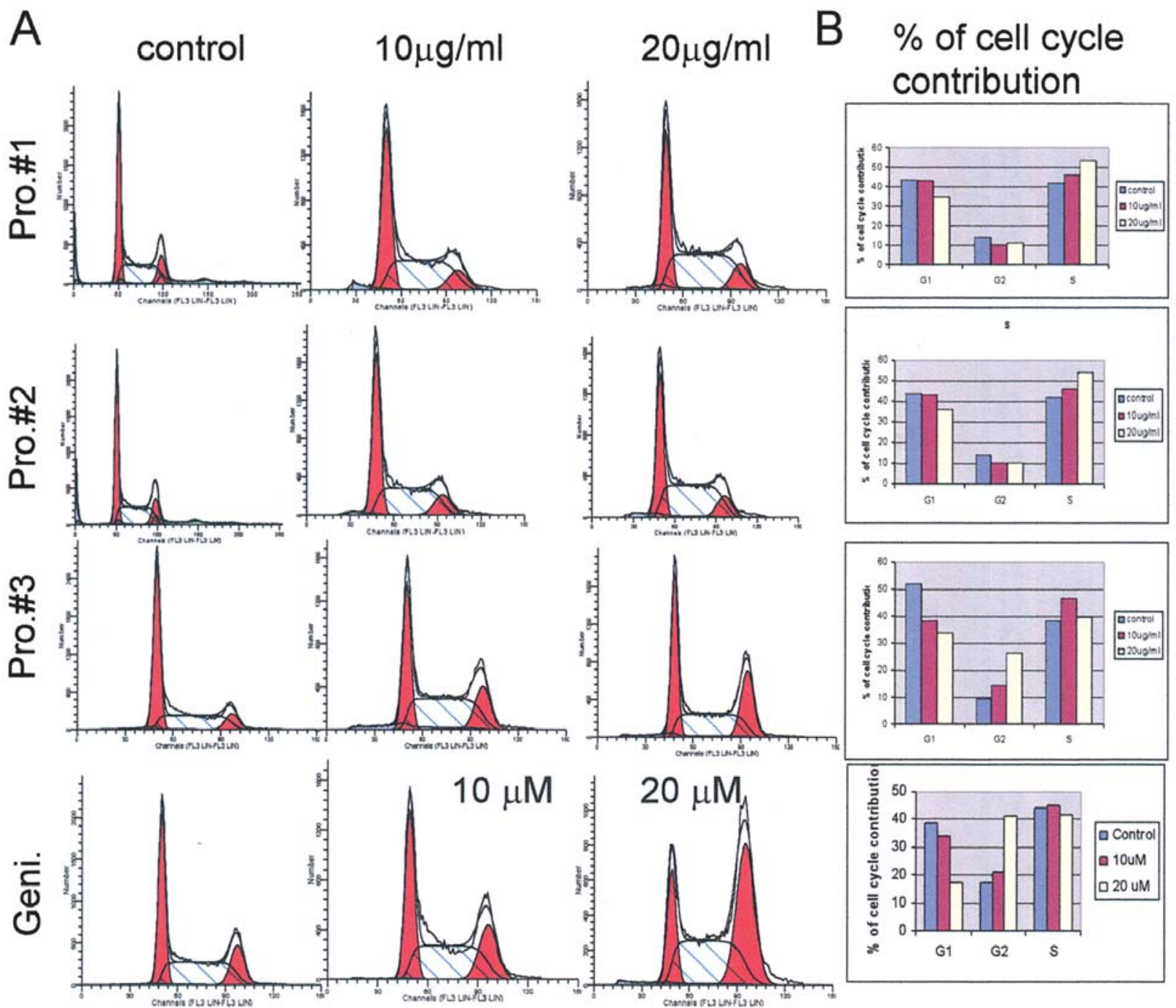

Figure 3. Effect of propolis on cell cycle progression in RC58T/h/SA\#4 cells in KGM medium. Cells were cultured in KGM medium and treated with either EtOH vehicle control or 10 and $20 \mu \mathrm{g} / \mathrm{ml}$ doses of propolis. After 24-h (Pro. \#3) or 48-h (Pro \#1, 2) treatments, cells were collected, washed with PBS fixed with 70\% ethanol, digested with RNase, and the cellular DNA was stained with propidium iodide. Flow cytometric analysis was then performed for cell cycle distribution. A, propidium iodide fluorescence pattern for cell cycle distribution using different treatments. B, percentage of cell distribution data for each treatment group.

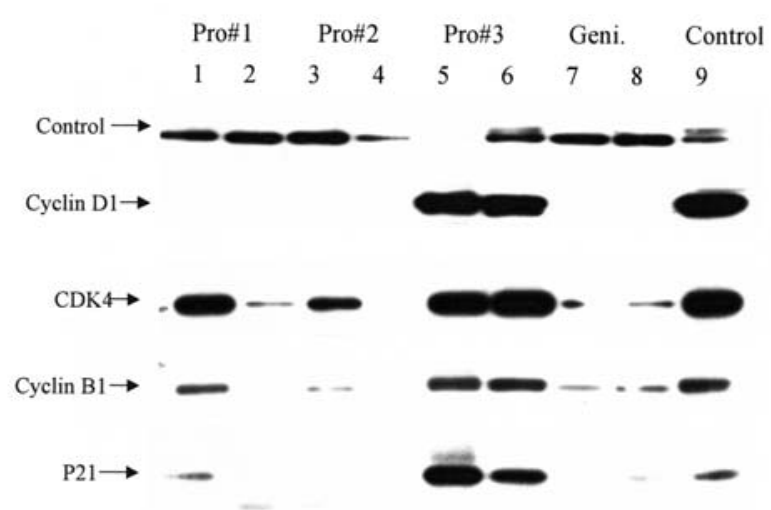

Figure 4. Propolis regulates cell cycle related protein expression in RC58T/ $\mathrm{h} / \mathrm{SA \# 4}$ cells. To investigate the molecular mechanisms of the cell cycle effects of propolis, we carried out Western blot analysis. The cell cycle related proteins cyclin D1, CDK4, cyclin B1 and p21 were examined. The results indicated that propolis \#1 and propolis \#2 had similar effects inhibiting the protein expression of cyclin D1, CDK4 and cyclin B1. Propolis \#3 did not affect the protein expression of cyclin D1, CDK4 and cyclin B1, but strongly induced $\mathrm{p} 21$ protein expression.
Effects of propolis samples on cell cycle progression. To test the effect of propolis samples on cell cycle progression in RC58T/H/SA\#4 cells and normal cells (data not shown), we treated the cells with the samples for 24 and $48 \mathrm{~h}$, and then examined the cells by flow cytometry analysis. The results showed that samples \#1 and \#2 arrested the cell cycle at the $S$ phase at $48 \mathrm{~h}$ and sample \#3 arrested the cell cycle at the G2 phase at $24 \mathrm{~h}$ (Fig. 3). Genistein was used as control.

Propolis regulated cell cycle related gene expression. To investigate the regulation of cell cycle related genes, we evaluated the protein expression using Western blot analysis by comparing cell lines that were untreated and treated with 10 and $20 \mu \mathrm{g} / \mathrm{ml}$ of propolis samples for $48 \mathrm{~h}$ (Fig. 4). The cell cycle related proteins cyclin D1, CDK4, cyclin B1 and p21 were examined. The results indicated that samples \#1 and \#2 had similar effects, inhibiting the protein expression of cyclin D1, CDK4 and cyclin B1. Sample \#3 did not alter the protein expression of cyclin D1, CDK4 and cyclin B1, but strongly induced p21 protein expression (Fig. 4). 


\section{Discussion}

Propolis is a resinous product collected by bees (Apis mellifera) from tree exudates, mainly resins of leaf buds mixed with beeswax to form a sealing material in their honeycombs, smooth out the internal walls, and protect the entrance against intruders $(2,3)$. Propolis has been shown to kill Bacillus larvae, the most important bacterial disease of bees (20). Flavonoids such as Chrysin and Quercetin account for much of the biological activity in propolis. Propolis has been shown to be highly antimicrobial and have an inhibitory affect on 21 species of bacteria and viruses (including herpes and influenza), antioxidant effects and anticancer effects. Propolis cytotoxicity on cultures of human and animal tumor cells, including breast carcinoma, melanoma, colon, and renal carcinoma cell lines (21). The component producing these effects was identified as caffeic acid phenethy ester. Substances isolated in propolis which produce this cytotoxic effect are quercetin, caffeic acid, and clerodane diterpendoid. Clerodane diterpendoid shows a selective toxicity to tumor cells. A substance called Artepillin $\mathrm{C}$ has been isolated from propolis, and has been shown to have a cytotoxic effect on human gastric carcinoma cells, human lung cancer cells and mouse colon carcinoma cells in vitro $(6,7)$.

In the present study, we observed for the first time that the ethanol extracts of Brazilian propolis significantly inhibit cell growth of metastasis-derived human prostate carcinoma (DU145 and PC-3 cells) and primary tumor derived human prostate cancer cells (telomerase immortalized RC-58T/h/SA\#4 cells). The strongest growth inhibition was observed in the sample \#3 (propolis group 3) extract. Furthermore, in the $\mathrm{RC}-58 \mathrm{~T} / \mathrm{h} / \mathrm{SA \# 4}$ cells, samples \#1 and \#2 (origin botanic of propolis group 12 and propolis group 12) induced growth inhibition that was associated with $\mathrm{S}$ phase arrest, whereas sample \#3 (propolis group 3) induced growth inhibition that was associated with G2 arrest. The mechanisms of cell cycle effects of samples were investigated. Samples \#1 and \#2 inhibited cyclin D1, CDK4, cyclin B1 expression. Sample \#3 induced p21 expression but did not effect cyclin D1, CDK4 and cyclin B1.

Cyclin D1 and cyclin-dependent kinase control the cell cycle from G0 to G1 phase and cyclin B1 controls the cell cycle from $\mathrm{S}$ to $\mathrm{G} 2$. The oncogene mitogens such as PDGF, IGF and EGF stimulate cell growth through altering cell cycle components. Higher expression of cyclin D1 and cyclindependent kinase proteins are associated with androgenindependent metastatic prostate cancer $(22,23)$. As we have demonstrated, the ethanol extracts of Brazilian propolis inhibited the protein expression of cyclin D1, B1 and CDK4. This inhibitory efficiency was attenuated by increasing the concentration of serum in the medium. The inhibition of cyclin D1 and B1 and the induction of p21 by Brazilian propolis suggests that Brazilian propolis could be useful alone or in combination with anticancer agents in prostate cancer chemotherapy as well as in prostate cancer chemoprevention. Since we do not yet know which compound plays a crucial role in inhibiting the protein expression of cyclin D1, B1 and CDK4, the search for a purified single compound from propolis as a potential chemopreventive and chemotherapeutic agent against prostate cancer is worthy of future investigation.

\section{References}

1. Jemal A, Murray T, Ward E, Samuels A, Tiwari RC, Ghafoor A, Feuer EJ and Thun MJ: Cancer Statistics. CA Cancer J Clin 55: 10-30, 2005.

2. Greenaway W, Scaysbrook T and Whatley R: The composition and plant origins of propolis. Bee World 71: 107-118, 1990

3. Chisalberti EL: Propolis - a review. Bee World 60: 59-84, 1979.

4. Matsuno T, Matsumoto $\mathrm{Y}$, Saito $\mathrm{M}$ and Morikawa J: Isolation and characterization of cytotoxic diterpenoid isomers from propolis. Z Naturforsch C 52: 702-704, 1997.

5. Vynograd N, Vynograd I and Sosnowski Z: A comparative multi-centre study of the efficacy of propolis, acyclovir and placebo in the treatment of genital herpes (HSV). Phytomedicine 7: 1-6, 2000.

6. Kimoto T, Aga M, Hino K, Koya-Miyata S, Yamamoto Y, Micallef MJ, Hanaya T, Arai S, Ikeda $M$ and Kurimoto M: Apoptosis of human leukemia cells induced by Artepillin C, an active ingredient of Brazilian propolis. Anticancer Res 21: 221-228, 2001.

7. Kimoto T, Arai S, Kohguchi M, Aga M, Nomura Y, Macallef M, Kurimoto M and Mito K: Apoptosis and suppression of tumor growth by Artepillin C extracted from Brazilian propolis. Cancer Detect Prev 22: 506-515, 1998 .

8. Basnet P, Matsuno $\mathrm{T}$ and Neidlein R: Potent free radical scavenging activity of propolis isolated from Brazilian propolis. Z Naturforsch C 52: 828-933, 1997.

9. Park YK, Koo MH, Abreu JA, Ikegaki M, Cury JA and Rosalen PL: Antimicrobial activity of propolis on oral microorganisms. Curr Microbiol 36: 24-28, 1998.

10. Ito J, Chang FR, Wang HK, Park YK, Ikegaki M, Kilgore N and Lee KH: Anti-AIDS agents. 48(1) Anti-HIV activity of moronic acid derivatives and the new melliferone-related triterpenoid isolated from Brazilian propolis. J Nat Prod 64: 1278-1281, 2001.

11. Burdock GA: Review of the biological properties and toxicity of bee propolis (propolis). Food Chem Toxicol 36: 347-363, 1998.

12. Bankova V and Marekov N: Propolis-chemical composition and standardization. Farmatsiya (Sofia) 32: 8-18, 1984.

13. Garcia-Viguera C, Greenaway W and Whatley F: Composition of propolis from two different Spanish regions. Z Naturforsch 634-637, 1992.

14. Konig B: Plant sources of propolis. Bee World 66: 136-139, 1985.

15. Park YK, Alencar SM and Aguiar CL: Botanical origin and chemical composition of Brazilian propolis. J Agric Food Chem 50: 2502-2506, 2002.

16. Park YK, Paredes-Guzman JF, Aguiar CL, Alencar SM and Fujiwara FY: Chemical constituents in Baccharis dracunculifolia as the main botanical origin of southeastern Brazilian propolis. $\mathrm{J}$ Agric Food Chem 52: 1100-1103, 2004.

17. Marcucci MC: Chemical composition, biological properties and therapeutic activity. Apidologie 26: 83-99, 1995.

18. Park YK, Ikegaki M, Alencar SM, Wang HK, Bastow K, Cosentino $\mathrm{M}$ and Lee KH: Determination of both cytotoxic and anti-HIV activities in ethanolic extracts of Brazilian propolis. Mensagem Doce 56: 2-4, 2000.

19. Gu Y, Kim KH, Ko D, Srivastava S, Moul JW and Rhim JS: A telomerase-immortalized primary human prostate cancer clonal line with neoplastic phenotype. Int J Oncol 21: 1057-1064, 2004.

20. Bosio K, Avanzini C, D'Avolio A, Ozino O and Savoia D: In vitro activity of propolis against Streptococcus pyogenes. Lett Appl Microbiol 31: 174-177, 2000.

21. Grunberger D, Banerjee R, Eisinger K, Oltz EM, Efros L, Caldwell M, Estevez V and Nakanishi K: Preferential cytotoxicity on tumor cells by caffeic acid phenethyl ester isolated from propolis. Experientia 44: 230-232, 1988.

22. Kallakury BV, Sheehan CE, Ambros RA, Fisher HA, Kaufman RP Jr and Ross JS: The prognostic significance of p34cdc2 and cyclin D1 protein expression in prostate adenocarcinoma. Cancer 80: 753-763, 1997.

23. Drobnjak M, Osman I, Scher HI, Melissa Fazzari M and Cordon-Cardo C: Overexpression of cyclin D1 is associated with metastatic prostate cancer to bone. Clin Cancer Res 6: 1891-1895, 2000 . 